\title{
THE POLITICS OF COMMUNITY ECONOMIC DEVELOPMENT
}

\author{
MitTON KotLER*
}

I

\section{Established Power and Poverty Reform}

In Ig67, three years after the passage of the Economic Opportunity Act, the White House began to have second thoughts about its original emphasis on community action and maximum feasible participation as a method for ending poverty. While the planners of the Act might have supposed originally that organized pressure by the poor could be accommodated by the system-as the system had accommodated so many interest groups-and conversely, that the organized poor would for this purpose abide by the rules of the game, the reality from the point of view of community organization was quite different. Community action based upon maximum participation was more than a tactical concept. It was the release of a potentially great force, namely, territorially organized citizen power. No other interest group has that "sovereign" base. Thus, organizations based on this principle were quite extraordinary compared to the normal varieties of interest groups which pressure the government. It soon appeared to the government not that the poor would willfully break the rules of pressure politics, but that the government had endorsed a principle of organization that itself transcended the character of interest group politics.

Mayors began to complain that the newly organized and funded neighborhood organizations were threatening the power of city government, and they sought to terminate these organizations and their funding, either directly from Washington or through the independent community action agencies. As a result of the complaint, Congress passed the Green Amendment, ${ }^{x}$ permitting mayors to get control of their cities' anti-poverty programs.

The new arrangement enabled the government to withdraw funding from neighborhood organizations which confronted city power and to begin to fund antipoverty programs within a pro-city framework. This rearrangement, in the sensitive world of politics, required a "felicitous" adaptation of the theory of poverty to which the political intention of placing OEO powers in the hands of the city management would conform. The new theory was local economic enterprise, referred to as "community economic development."

But the capture of political control over OEO did not solve the mayors' poverty

- Resident Fellow, Institute for Policy Studies, Washington, D.C.

${ }^{1}$ Economic Opportunity Act (I967 Green Amendment), 42 U.S.C. $\$ \$ 2790,279 x, 2795,2796$ (Supp. $\mathrm{V}$, I969). 
problems. The cities were still disproportionately populated by poor people, and their rate of increase in coming years would, by all projections, be very high. One political view was that there would have to be some absorption of members of the lower class into the established order to decrease the number of poor and to create a group from this membership which would control those who remained. Given this understanding, it seemed most feasible to shift the funds of the OEO program from those who had formerly organized the poor to confront city government to those among the poor who had the greatest ambition to enter the system. Since being in the system of our society means making money, the new patronage would go to those in the poor community who wanted to make money, rather than to those who wanted to organize the poor politically.

This signaled an important shift. While job training and manpower programs were part of the first community action programs, this training had emphasized job placement in factories and other business establishments of the city. Now the idea was to encourage the enterprising people in the communities, and assist them to establish small businesses and little industries which could employ the poor people. And it was to be this group of people-those ambitious for gain-on whom established power would place the task of cooling off the cities. They thought this would demonstrate the mobility of the system and, at the same time, suppress the political movement of the underclass.

Since late rg68, and until the present, OEO funding money has gone to economic development projects. The community organizations which started earlier under the community action program had to reorient their grant proposals in the direction of economic development in order to remain funded. A variety of approaches was taken to accomplish this shift: assistance to small business in the poor community, small industrial development in the poor neighborhood, cooperative arrangements with big corporations, community ownership schemes for merchandising and home purchasing.

This is the present state of the government's anti-poverty program, but it is already on the way out. The new program of family assistance represents the next step in the government's political program for the poor. Family assistance, which is likely to spell the demise of OEO as a program agency, returns to an old welfare notion-to wit, financial assistance on the basis of low-wage labor. The appearance of this development upon the scene raises the question of how much energy the professional should now invest in a conception of community economic development based on federal assistance. In short, while the idea of community economic development is still promoted by the government, ${ }^{2}$ the cycle of anti-poverty initiatives is turning back to a government commitment to individual labor welfare rather than community economic development.

\footnotetext{
${ }^{2}$ For a brief account of the dubious nature of this support, see Boasberg, The Washington Beat: The Urban Law Center-an Emerging Concept, 2 UrbaN LAWYER 553 ( 1970 ).
} 
Family assistance is only part of the present administration's program for dealing with the political problem of the urban poor. The regional movement for metropolitan government, also part of the establishment's agenda, is hailed as the best way to cure the political ills of the city. This movement calls for the expansion of urban government on the basis of multi-county consolidation. The origins of city expansion are quite old, dating back to the first colossal enlargement of Philadelphia from an area of $I-1 / 2$ square miles in $I 854$ to its absorption of the entire county of Philadelphia in that same year. The reasons for the annexations and consolidation in the nineteenth century were varied, but by the second decade of this century, a resistance to annexation had slowed the pace of municipal growth. Following World War II, there was a spate of annexations, particularly in the South and West, and more recently the expansion drive has reappeared in the guise of regionalization and metropolitan government. The general arguments which are advanced for this movement are based on its potential for increasing tax resources, tax equalization, and operational efficiency. But it is the political intention of this movement which must be considered as its most significant aspect.

Since the I950's, the cities have been losing their middle-class and wealthy residents at a fast rate to the surrounding suburbs. While this phenomenon has been decried from the point of view of a loss in tax base, it has also disturbed the old pattern of public services and welfare distribution which ensured the political control of downtown power. The administrative practice of giving better services to the middle-class population cannot today produce the former political results because of the decreasing population of that class in the city. In addition, the cost of applying the former service standards of the middle-classes to the poor, combined with an increase in welfare spending, is prohibitive. Aside from the cost, there is the further problem that long-established habits of public service work against any attempt to increase the services and welfare directed to the poor. Both the political structure and the administration of the city are being eroded because of the government's failure to adjust to the new class composition of the cities.

There are only two possibilities which will allow the cities to continue as viable propositions in the face of this population change. Either the city government must change its political constitution to adapt to its new class compositon or the cities must absorb the entire middle-class population that has fled to the suburbs. Apparently, the politicians have chosen the latter course, opting for a program of regionalization which preserves downtown as the political and commercial center of the metropolitan area, neglects the slum city (which is fast coming to mean the entire present city limits), regains the familiar suburban middle-class as the social base for a new constituency, and proceeds with traditional patterns of public service administration.

The consequence of this movement toward metropolitan government is clear; it means the displacement of public services from within the city limits to the suburbs, 
and the establishment of some police arrangement to control the immensely expanded slum of the present city. The economic prescription of the metropolitan strategy would nullify any necessity for community economic development in the old city neighborhoods, for the government of downtown power can find its economic foundation in the suburbs.

II

\section{The Politics of Community Organizations}

Turning to the question of community economic development in the neighborhood organization, we see a much different line of development of the issue. There was nothing particularly complex about the original theory of community action and its strategy of maximum feasible participation. It was thought that the best route toward eliminating poverty was to organize the poor politically in the cities or rural areas, so that they could pressure government for a greater share of public resources for services and welfare. It appeared to be an intelligent idea in three respects. First, in recognized the conventional view that to get fairer laws, better public services, and more money from the public treasury, you have to organize and put pressure upon government. The political scientists had been saying this for years, in innumerable books on pressure politics and interest groups. Thus, poverty was, like any other special interest, subject to the application of this maxim of politics.

The second element of the organization-action approach was that the neighborhood was the best base for organizing the poor. This is obvious enough because the poor, unlike doctors and lawyers, are associated in territories. The third element favoring this approach was the maximum participation stipulation. The greatest power the poor have, after all, is their numbers and their collective intention and action.

As a matter of fact, the community action method, in all its simplicity, was quite ingenious and produced results in organization and pressure. It gave a political structure back to neighborhoods which had lost their political identity because annexation and municipal reforms had destroyed the power of the neighborhoods at both the municipal and ward levels.

It was obvious to community leadership, however, that when independent, federally funded organizations based upon maximum participation began to appear, the government would withdraw support. But it was also apparent that only these principles of participation and organization could produce the political results desperately needed by the poor.

Thus, from the inception of the Community Action Program and the first funding of independent neighborhood organizations, it was clear that the crucial questions concerned the amount of funding available to those who would organize the neighborhoods as a unit of power and whether that funding could be retained in 
subsequent years. If the basis of anti-poverty theory were community pressure, then funding would be a problem of supporting a mix of political organization and political education as well as enough programs of direct social benefit to tie residents into the neighborhood organization.

As for the matter of getting re-funded the next year, that problem was met in terms of political strategy. It was resolved by a delicate combination of efforts at building community political power and at the same time boxing the government into a re-funding commitment. On this basis, some organizations were able to blend into the re-funding process, moving two steps forward and one step backward. Other organizations failed to take a step backwards; their militancy was too exposed, and they lost their funding.

From the outset it was apparent that eventually, tactical error, or a major change in government policy or law, would remove most organizations from the funding train, and that another source of funding - an independent source-had to be found. This problem is elaborated to draw out the reality of the economics of community organization and to show the error of the conventional notion that the economics of the anti-poverty program meant lifting individuals out of poverty-pulling people above the poverty line. It was true that many people were lifted above this line, but this was largely because of staff jobs in neighborhood organizations geared to providing either political education or the social benefits necessary to tie people to political organization.

When the federal policy changed in 1968 , and favor shifted from community action based upon maximum feasible participation to community economic enterprise, it seemed to contain a possible temporary solution to the problem of funding the neighborhood political organization. The government wanted enterprise rather than political action in the neighborhood; it would move the people out of the meeting hall and put them behind cash registers. The community organization could not expect continued federal funding and hence, its survival depended upon generating enterprises whose profits could pay for the organization and its political program. An array of ventures and offers of assistance appeared, including federal grants and loans for capitalization, and training assistance from large corporations. Also, the government uncharacteristically acquiesced to such notions as community ownership. Anything, even socialism, was preferable to continued funding for neighborhood political organization.

The new line was received in the community with mixed feelings. On the one hand, political organization could not be abandoned. On the other, community ownership and enterprise assistance was also important. An infusion of wealth into the communities was consistent with the long-range need of a base of local wealth to support political organizations. And, of course, new wealth would promote the long-range objective of community prosperity. In short, at this period, it was clear that the only means to neighborhood improvement was through the establishment of 
independent community organizations, and it was also clear that the community had to have an internal economy capable of supporting itself.

Faced with the new economic policy of $O E O$, the community organizers agreed to write grant proposals promoting entrepreneurial development based on private enterprise or community ownership. But they also understood that tactically as much money as possible under these economic programs would be applied to the political objective of organization; that is, they would continue political organizing in a community development framework. The result would be that the political organization could continue while attention was paid to developing a local economy. Further, the priority of economic enterprise would accord with the requirements of advancing political organization. Housing projects and supermarkets were high on the economic development list, although in a number of cases workshop production of goods was undertaken.

This is the state of things in poor communities at the present time. Many organizations have ceased to exist because they failed to make the economic shift, and a more radical politics have taken over in those neighborhoods. What the government failed to appreciate was that under the community action program they were indeed paying for political education and political action in the neighborhoods, but for a kind that had peaceful possibilities, albeit under a political rearrangement of the municipal constitution. By withdrawing funds, the government antagonized the communities and made their situation more desperate.

The present represents a new stage in the area of community development. Community action organizations that lost funding had to find new sources of support. Those continuing political work with funds received under the rubric of community economic development must discover a way to free themselves from dependence on government money if they hope to achieve their political aims. Regionalization challenges the community organization in the ghetto to strive for independent political control in their own neighborhoods rather than endure the police control which would prevail under a metropolitan plan. The prospect of regional government alters the economic question as well. Since regionalization suggests a new unity between the government downtown and the middle class in the suburbs, the likelihood of a viable, independent economy in the neighborhood further diminishes. And to relate the political and economic questions, it appears that the politically organized neighborhood is obliged to be the principal developer of its own economy.

\section{III}

\section{NeIGHBorhood SeLF-SUfFicIENCY}

The conclusion to be reached, then, is that community development efforts cannot rely on outside sources to improve the economy of the neighborhoods. External funding will end with the advent of the government's regionalization program. 
Under this condition, there is no future for the government assistance to small enterprise in the neighborhoods, or even for employment training for the poor, since the function of regionalization will be to dissociate the present cities from the economy of production in the suburbs. The problem of community economic development is rather the capacity of the neighborhood organizations to build a self-sufficient economy, first to support its own local political control and, second, to support the prosperity of its inhabitants through a local basis for internal and external trade. It is a harsh conclusion to place such great responsibility on the neighborhood organization, but this is the desperate necessity which the political maneuvers of the government have imposed upon the poorer neighborhoods. There is, however, a way by which the poor neighborhood can confront the problem of economic development and independence.

The important features of a poor neighborhood are, first, the discrepancy between the aggregate expendable income of the neighborhood and the paltry level of its commerce and, second, the discrepancy between the considerable tax revenue the neighborhood generates and the low level of benefits it receives in public services and welfare. In both cases, the neighborhood exports its income. Hence, the income and tax revenue of the neighborhood is of no service to its economic and political development. Its present internal commerce is dependent, as is its level of public services, on commerce and personnel outside the neighborhood.

With regard to expendable income, the familiar picture of the poor neighborhood is that its residents spend the largest part of their income outside their territory and another part in commerical places and for rents inside the territory to corporations or individuals who reside outside the neighborhood. In all, a very small portion of the income remains within the neighborhood. Thus there is a steady and unrelenting dependence characterized by a dollar drain which the residents replenish through outside employment.

Over the last decade, the proportion of external to internal expenditure for consumer goods has increased. There is a variety of reasons for this, including changes in residential patterns, downtown marketing, and transportation. Within the neighborhood there is, correspondingly, a sharp contraction of marketing and commerce. Small store after small store is closing up. Food marketing is confined to chain stores in a pattern which also applies to furniture and clothes.

Smaller and older shops find themselves unable to cope with either the political conditions of the neighborhood or the competition from chain stores. The business these stores might have counted on is absorbed by the stores which can offer low prices by buying in quanity and expanding to meet the needs of new shoppers. This trend has sharply reduced the commercial energy of the neighborhoods and it is likely that soon the only trade left within the poor neighborhoods will be for food and rents. Furniture, appliance, and drug stores as well as many other kinds of trading establishments are leaving poor neighborhoods. As for rents, landlords in 
many areas are simply abandoning their property because of the difficulty of collecting rent and the expense of repairing old buildings. As the trend develops, the proportion of income expended within the neighborhood for commodities will decrease and a greater share will go downtown.

So the picture of the neighborhood economy is one of increasing barrenness. The destruction wrought by riots in the past decade, combined with the failure of store owners to rebuild and of the city to assist commercial redevelopment, contributes to the trend. Because commercial decline is consistent with the metropolitan strategy, there is no lending and capitalization for new ventures in poor black neighborhoods. Commercial initiatives in the poor neighborhoods are viewed as adventures, not as commercial undertakings.

A similar pattern of net outflow is revealed upon comparison of the value of public services received in exchange for neighborhood tax expenditures. In his study of the Shaw-Cardozo neighborhood of Washington, D.C. ${ }^{3}$ Earl Mellor reveals a tax payment of $\$ 44$ million from a population of 87,000 . This amount comes out of an aggregate personal income of \$I44 million for the area. Mellor calculates that the dollar value of visible public services and welfare received is below $\$ 34$ million by the most likely measure of the distribution of public services in a city, namely wealth. Therefore, there is a net outflow of \$1 million from the neighborhood tax payment.

Furthermore, taxes paid out go largely to public employees such as policemen and teachers who live outside the neighborhood but who come into it to perform their services, and partly to welfare recipients in the neighborhood itself. This is analogous to the expenditure of the greater proportion of income for commodities and rent in commercial establishments outside the neighborhood (or inside establishments which are externally owned). This disproportion is even more dramatic because, as Mellor suggests, out of a calculated minimum benefit of $\$ 34$ million for Shaw-Cardozo, welfare payments, social security, and unemployment compensation amount to \$ro.9 million, or 23 per cent of the payment. Thus, of the $\$ 44.6$ million paid in taxes by the neighborhood, only about \$ro.9 million of that is received back in cash. Hence, Cardozo exports about \$33.9 million a year to pay for services, just as it exports the greatest portion of its expendable income outside for shelter and commodities. If the trends in taxation continue and if the government achieves its announced intention of reducing the welfare load, the disproportion of tax revenues for public services will also increase.

The bulk of tax revenue pays for personnel who live outside the neighorhood. And, despite recent rhetoric concerning decentralization of public services and welfare administration in the city, we find that residents of the neighborhood must increasingly go outside the neighborhood for the services their taxes support. The variety of public service activity originating in, or with offices located in the neighborhood, is steadily reduced and concentrated. As an example, while the neighborhood

\footnotetext{
${ }^{3}$ E. Mellor, Public Goods and Services: Costs and Benefits (mimeo., Institute for Policy Studies, I969).
} 
pays taxes for education, the latest tendency is for its school children to be bused out of the neighborhood to schools in the far reaches of the city. Health care facilities are increasingly centralized, or locally unavailable. The same is true for fire prevention, welfare administration, police, and vocational rehabilitation. As with the trend in commodities, the trend in public services marks a decline in neighborhood location.

In view of these conditions, it can be said that the principal characteristic of the poor neighborhood is not its poverty but the diminution of its commerce and public administration. Its residents earn a considerable expendable income, in the aggregate, and pay considerable taxes. This payment must, however, be understood as support to the economies of neighborhoods outside the poor neighborhood. With the advent of metropolitan government, the slum city will continue to earn income, but its expenditure for commodities will constitute a primary support for a commercially-renewed downtown and its tax payments for services will be a primary support to the suburbs whose middle class population will increasingly be involved in public employment.

The result of this tendency will be stagnation and decay for the neighborhoods of the present city. They will have few commercial or public service activities of their own. They will be locked into a dependent relationship with the suburbs and downtown which will foster further erosion. If one accepts the statement of Rousseau that "it is impossible to make any man a slave unless he first be reduced to a situation in which he cannot do without the help of others," he must conclude that the poor neighborhood has become economically enslaved, not because of an absence of income, but because of its dependence upon outside economies for commodities and public services.

The primary economic problem of the neighborhoods today is not to increase the aggregate income, for no matter how that income increases, its flight-in payment for commodities and public services-will also speed up. The net effect will be to strengthen a downtown economy and suburban bureaucracy. This result can be prevented only if the neighborhood can create an internal economy and political control to attract and keep its expendable income for commodities and public services. The internal expenditure for these two necessities is related, in that tax payments to neighborhood employees for services performed can contribute to commercial activity in the neighborhoods. Thus, the resulting commercial prosperity can become a stronger base for neighborhood taxation.

The conventional conception of community economic development in the poor neighborhoods has been the direct organization and establishment of indigenous enterprise, whether owned privately or by some community organization. The two major difficulties with this approach have been capitalization and marketing management. If businesses were successful in original capitalization, they often collapse 
because of marketing difficulties, whether through disorganization or because they could not meet the competition.

The problem of capitalization cannot be met simply through privately-owned lending institutions because such banks cannot survive the trial and error of commercial development that aims to achieve a marketing and management organization suitable to the environment of poor neighborhoods. Nor can a capitalization program be based on the unreliable expedient of federal programs which may put \$100 million in black banks one year and nothing in them the next. In short, the ingredients for a successful capitalization program must include substantial funding, regularly available investments, and independence from profit-making. In short, capitalization for neighborhood economic development must be conceived of as a public service and based upon an internal tax.

On the basis of the figures denoting outflow of taxes from the Cardozo neighborhood, it is apparent that funds for neighborhood capitalization programs must come from the $\$ 44.6$ million paid by that area in federal and city taxes. Since Mellor's study demonstrates that there is a net outflow of tax revenue, any neighborhood which could retain this excess would have an annual capital fund of \$ro million for economic development, without affecting the present level of public services and welfare. With capitalization of an internal economy as a priority, its capitalization fund might be even greater as would be the quality and efficacy of its services and welfare programs.

The question of a suitable form of neighborhood commercial organization cannot be taken up without answering first the question of whether effective commercial organization can precede political organization. If the only feasible strategy for neighborhood capitalization is neighborhood taxation, then the retention of neighborhood tax revenues and administrative control of their expenditure will of necessity be the organizational context of, and the precedent for, the appropriate organization of commercial development.

In summary, it is the thesis of this article that reliable community economic development can only evolve out of the existing fiscal resources of the neighborhood, and that such resources exist in neighborhood tax expenditures. This application is consistent with the aims of community action which, although originally seeking to pressure city government for fair distribution of services and welfare, must take its course from the rebuff of government with its insistence on regionalization, and move toward self-control through neighborhood government. 